\title{
Application of Soft Systems Methodology in Defining Professional Communication Skills for Malaysian Graduates
}

\author{
Ahmad-Tajuddin Azza Jauhar, Ganakumaran Subramaniam \\ Department of Languages and Communication, Center of Fundamental and Liberal Studies, \\ Universiti Malaysia Terengganu, Malaysia. \\ azzajauhar@umt.edu.my \\ School of Education, University of Nottingham Malaysia Campus, Selangor, Malaysia.
}

Ganakumaran.subra@nottingham.edu.my

\begin{abstract}
This paper investigates the usage of Soft Systems Methodology (SSM) as an assessment tool for improving teaching and learning English in Malaysian higher education institutions (HEls). In this study, the Malaysian stakeholders - industries, government agencies of Malaysia and HEls - are the 'interveners' who create the best solutions of the problematic situation of poor professional communication skills amongst the graduates. By using SSM, it is anticipated that stakeholders involved would reach a common ground in defining Professional Communication Skills (PCS), which will decrease the problem of skill mismatches. It is discovered that SSM was able to examine the requirement from all parties by offering them a proper and equal stage to voice out their opinion. It is believed that SSM can help instructors and policy makers of Malaysian HEls in making a sound judgement in teaching PCS in classrooms, and help to develop our graduates' potential to be more marketable employees.
\end{abstract}

\section{Indexing terms/Keywords}

Soft systems methodology; professional communication skills in English; employability; English in higher education.

\section{Academic Discipline And Sub-Disciplines}

Higher Education, TESOL, Research methodology

\section{SUBJECT CLASSIFICATION}

English as a Second Language.

\section{TYPE (METHOD/APPROACH)}

Soft Systems Methodology, Qualitative Research.

\section{Council for Innovative Research}

Peer Review Research Publishing System

Journal: International Journal of Research in Education methodology

Vol . 6, No.3

ijremeditor@gmail.com

www.ijrem.com 


\section{INTRODUCTION}

Given the challenges facing the higher education institutions in Malaysia, the issue of the quality of English in Malaysian higher education (HE) institutions cannot be taken lightly. Firstly, there is a lack of holistic and comprehensive research on current English for Occupational Purposes (EOP from here onwards) curriculum practices in Malaysian HEls. The quality of teaching English in Malaysia has been debated with the evidence of the decreasing of English language proficiency level among Malaysia's university graduates (Gill, 2005; Lim, 2008; Mohd Radzuan \& Kaur, 2010; Noor Azina, 2011; Rasul, Ismail, Ismail, Rajuddin, \& Amnah, 2009). English education, particularly in higher education (HE), has been in the limelight mainly due to the many negative testimonies. Findings from the National Institute of Research in Higher Education (IPPTN) discovered that Malaysia is grappling with the quality issues in HE which impacted on its unemployability figures at worrying $48.5 \%$ (IPPTN, 2010). However, studies discovered that employment in Malaysia is set back by educational and skill mismatch, which occurred when HE institutions produce a new workforce that cannot enter the labour market because of the differences in what they perceive is needed in the market and what is actually needed (Koo, Pang, \& Mansur, 2007; Shafie \& Nayan, 2010; Wong \& Ming, 2010).

Hence, to overcome this problem, this research will determine the key definitions of professional communication skills identified by Malaysian stakeholders - Malaysian based multi-national companies, government agencies and academia for successful workplace function. The study covered a total number of 24 respondents in the following subgroups: 1) human resource managers from multi-national key industries (10 respondents); 2) government executives who recruit entry-level employees for public sectors (4 respondents) and; 3) EOP instructors and HE liaison officers for industrial training (10 respondents). The data obtained were subjected to computer assisted qualitative data analysis software (CAQDAS), namely ATLAS.ti 7.0 and sits within the interpretivist tradition. Additionally, in completing this objective, soft systems methodology will be applied in understanding this issue.

\section{OVERVIEW OF SOFT SYSTEM METHODOLOGY}

Soft Systems Methodology (SSM from here onwards) has been the outcome of a huge and thoughtful research work by Checkland and his colleagues to create a general framework, which able to tackle ill-structured problems faced in most of the interrelationships with their fellows (Delbridge, 2011). SSM is a systemic approach, whereby the systemic view recognises that the parts and internal relations of a system are dependent on its environment (Checkland, 1986; Checkland and Scholes, 1990). Checkland and Poulter (2010) describe SSM as an organized way of tackling perceived problematical social situations. It is action-oriented, whereby it organises thinking about situations so that actions can be taken to improve problematic situations. SSM is generally applied to situations where there are conflicts among stakeholders or where the goals of a system are debatable (Morcos \& Henshaw, 2009). In addition, the core aspects of systems thinking are gaining a bigger picture (going up a level of abstraction) and appreciating other people's perspectives. Checkland (2000), in his thirty year retrospective of SSM, affirms that a system can never be studied in isolation, but must be seen in relation to its environment. This approach provides conceptual tools for modelling the system as well as the environment in which the system is located (Tajino and Smith, 2005). The systemic approach depicts the system's environment as being composed of various interveners and active processes that influence the system (Avenier, 2002).

In the case of this study, the stakeholders - industries, government departments of Malaysia, HE institutions and the graduates themselves are the 'interveners' who are searching, grasping and creating the best solutions of the problematic situation of poor professional communication skills amongst the graduates. Applying SSM in this research will hopefully clarify and explore solutions to the problem of incompetence of Malaysian graduates in English at workplace. Researchers agree that the potential benefits of SSM is not only used to clarify objectives in complex and dynamic problem situations but can also be used to explore actual and future needs (Hassan, 2012; Patel, 1995). It can also act as an intellectual systemic tool to orchestrate and implement change in the real world in topics concerned to human affairs. It is a framework composed by seven steps organized in a special manner (See Figure 1) that leads to the implantation of culturally feasible and systemically desirable changes in human organisations of any kind (Checkland, 2000).

Agreeing with the views of Rose (1997), Hindle (2011) and Liu et.al.(2012), SSM is suitable for social sciences research, as this one, since it involves all stakeholders during all stages and it will ensure that their views are reflected in the outcomes and their acceptance of the new system by validating the proposed solutions or framework. The version of SSM presented in this study is most closely associated with the work of Peter Checkland, as presented in Checkland and Scholes (1990) and Checkland and Poulter (2010). 
Figure 1 Checkland's seven-stage soft systems methodology

\section{Methods}

The role of researcher in the context of SSM approach is to identify the ill-structured problem and try to improve the problem in a given situation. For the purpose of this study, SSM was used to assist researcher to explore the real world situation of graduates' PCS required by three groups of Malaysian stakeholders.

In stage 1 and 2 the researcher tried to develop the richest picture possible of the problematic situation. The function of these 2 stages was "to display the situation so that a range of possible and, hopefully, relevant choices [of relevant systems to be described in the following stages] can be revealed" (Checkland, 1986: pp. 166). Rich picture was employed as a method of capturing the problem situation; recognising that different stakeholders had diverse views and experience to fit their requirements of Professional Communication Skills among Malaysian graduates. Through rich-pictures, such different world-views (known as Weltanschauungen amongst SSM scholars) were highlighted. Such pictures could also draw attention to the degree of social interaction and begin to focus on issues which were considered purposeful and critical, as well as eliminating mismatches and disagreement associated with PCS between the stakeholders involved. The rich picture portrayed all the key players involved in the process and presented a structured view by putting into context the factors affecting the process. To enter to its way of working and application, it was necessary to present the rich picture, as being illustrated below (Figure 2). 
Figure 2 Rich picture: An area of concern on the Malaysian graduates' level of PCS generated from field data.
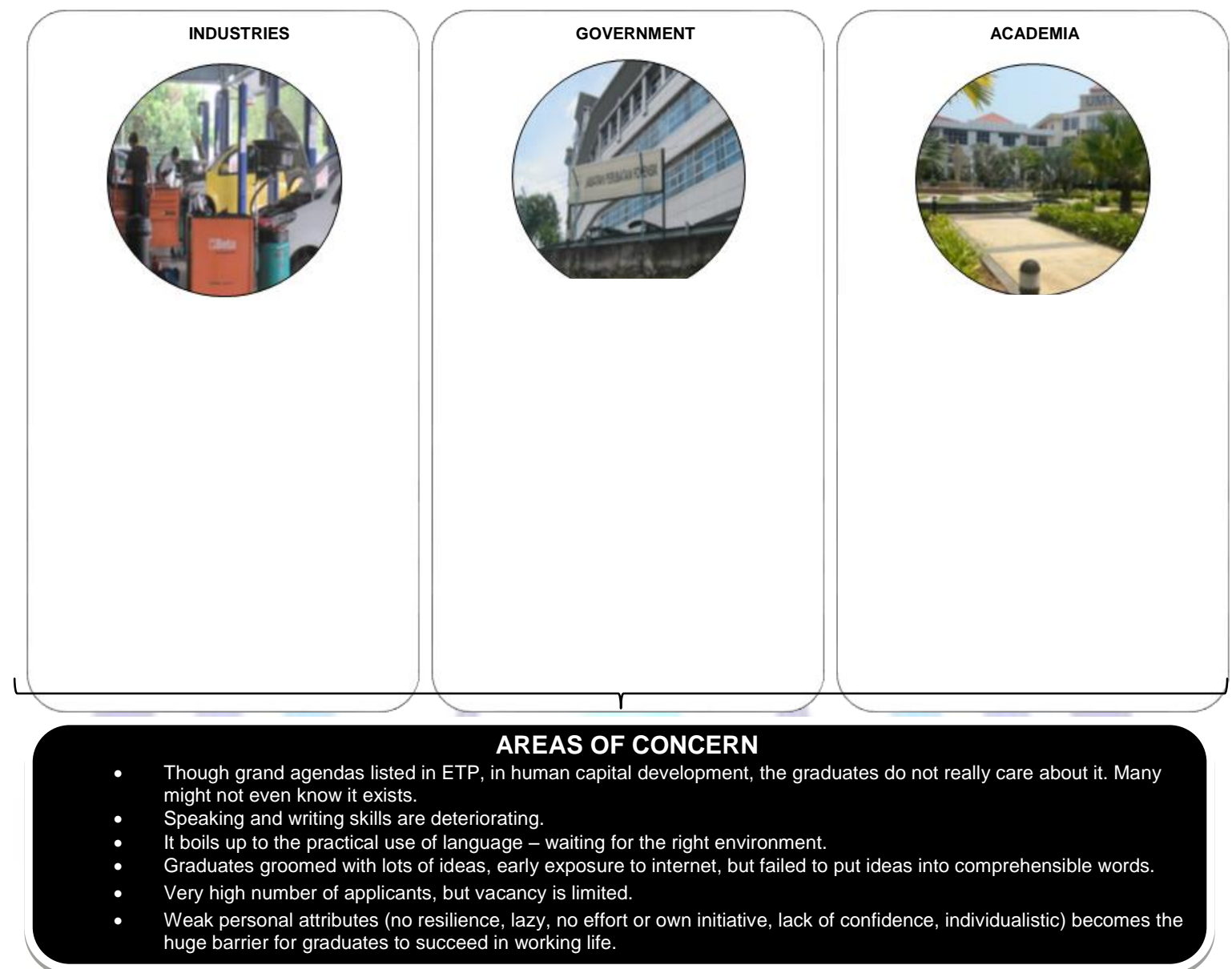

Meanwhile in Stage 3, Patel (1995) has used SSM's root definitions to identify responsible actors, key transformations, and the knowledge resources that are appropriate to the needs of all stakeholders. A root definition 'expresses the core intention of a purposeful activity system' (Wells, 1995) and is structured into three distinct parts: the 'what', the 'how' and the 'why'. The what is the immediate aim of the system, the how is the means of achieving that aim, and the why is the longer term aim of that purposeful activity (Platt and Warwick, 1995). Another significant characteristic of SSM is that the root definition must include a number of elements, which Checkland and Scholes (1990, pp.32) characterise under the mnemonic 'CATWOE' and the definitions of CATWOE are listed in Table 1 below.

Combining the elements identified in the rich picture (Figure 2), the subsequent main issues and CATWOE analysis, the following root definition is constructed for Professional Communication Skills (PCS):

"PCS is a system that provides a list of necessary skills for workplace communication in English language. PCS framework is initiated and validated by stakeholders (companies, government of Malaysia and academia) in ensuring Malaysian graduates to be highly employable. The PCS framework will feed into the education system and worker training schemes to generate quality workforce with the right skills needed. It ensures greater effectiveness and efficiency in teaching and learning in HE institutions."

In stage 4, Venters, Cushman, \& Cornford (2002) further describes how SSM can be used to develop conceptual models that identify patterns in knowledge activities. Such patterns can be used to provide a basis for technical design and organisational and social intervention. Based upon the need to address the problems in developing fluent communicators amongst Malaysian graduates, the following model to apply SSM has been developed (Figure 3) and is being incorporated into investigations in this research. 
Table 1 Definition of CATWOE in this study

\begin{tabular}{|c|c|}
\hline $\mathrm{C}=$ Customers & $\begin{array}{l}\text { - Malaysian HE institutions students who are } \\
\text { lacked of ample PCS upon graduation }\end{array}$ \\
\hline$A=$ Actors & $\begin{array}{l}\text { - Lecturers, English language instructors as } \\
\text { well as policy makers in HE institutions. }\end{array}$ \\
\hline $\mathrm{T}=$ Transformation process & $\begin{array}{l}\text { - Clear cut PCS Framework initiated and } \\
\text { validated by stakeholders which can be } \\
\text { implemented during and teaching and } \\
\text { learning process in Malaysian HE institutions. }\end{array}$ \\
\hline W $=$ World View (Weltanschauung) & $\begin{array}{l}\text { - The belief that validated PCS Framework by } \\
\text { all stakeholders would correct many skills } \\
\text { mismatch of the Malaysian graduates and wil } \\
\text { produce higher quality human capital } \\
\text { development. }\end{array}$ \\
\hline $\mathrm{O}=$ Owner & $\begin{array}{l}\text { - MOHE, Government of Malaysia } \\
\text { - Confidentiality issues in certain companies, } \\
\text { time availability of high ranked personnel in } \\
\text { MOHE. }\end{array}$ \\
\hline
\end{tabular}

The remaining stages are again set in the real world where action can take place. During stage 5 the ideal conceptual model is used to find similarities and differences with the perceived real world model. This has been shown in Figure 3 (the process below the dotted lines). The comparison between the conceptual model with reality is done by asking feedbacks from all stakeholders as well as an expert on Professional Communication Skills.

During Stage 5, the researcher leaves the systems thinking (or in this research context, the theories of communications) and initiates the debate concerning desirable feasible changes by setting up discussions which compares the models build in stage 4 with the problem situation expressed in stage 2. As Checkland and Scholes (1990) suggested, in ensuring the whole model works, researchers must focus on the intention of building of the models, which are to - 'debate' ( $p$. 42-43) and 'accommodate' (ibid. p. 28-30).

The purpose of the conceptual model is to question and debate whether the activities from the model (the skills enlisted in PCS framework) can be extended in the real world, how well can it accommodate and function, and the debate is also to find if alternative and better ways of doing them could be suggested. Informal discussion and formal questioning were implemented during this study. This took place during the second interview sessions, when the stakeholders has the chance to look back at what has been discussed during the earlier interviews and validate the framework by giving more feedback and criticism. This stage offers member-checking process to be implemented.

From various researches, many agrees that stage 7 may seem to be the last stage, but in human activity systems an apparent improvement simply creates a new situation which unsurprisingly creates new problems (Delbridge, 2011; Morcos \& Henshaw, 2009; Tajino \& Smith, 2005). The SSM model, in good practice, is cyclic and continual. However, since time factor was an issue, this stage is still working in progress. 
Figure 3 Conceptual model of the study divided into practical phase.

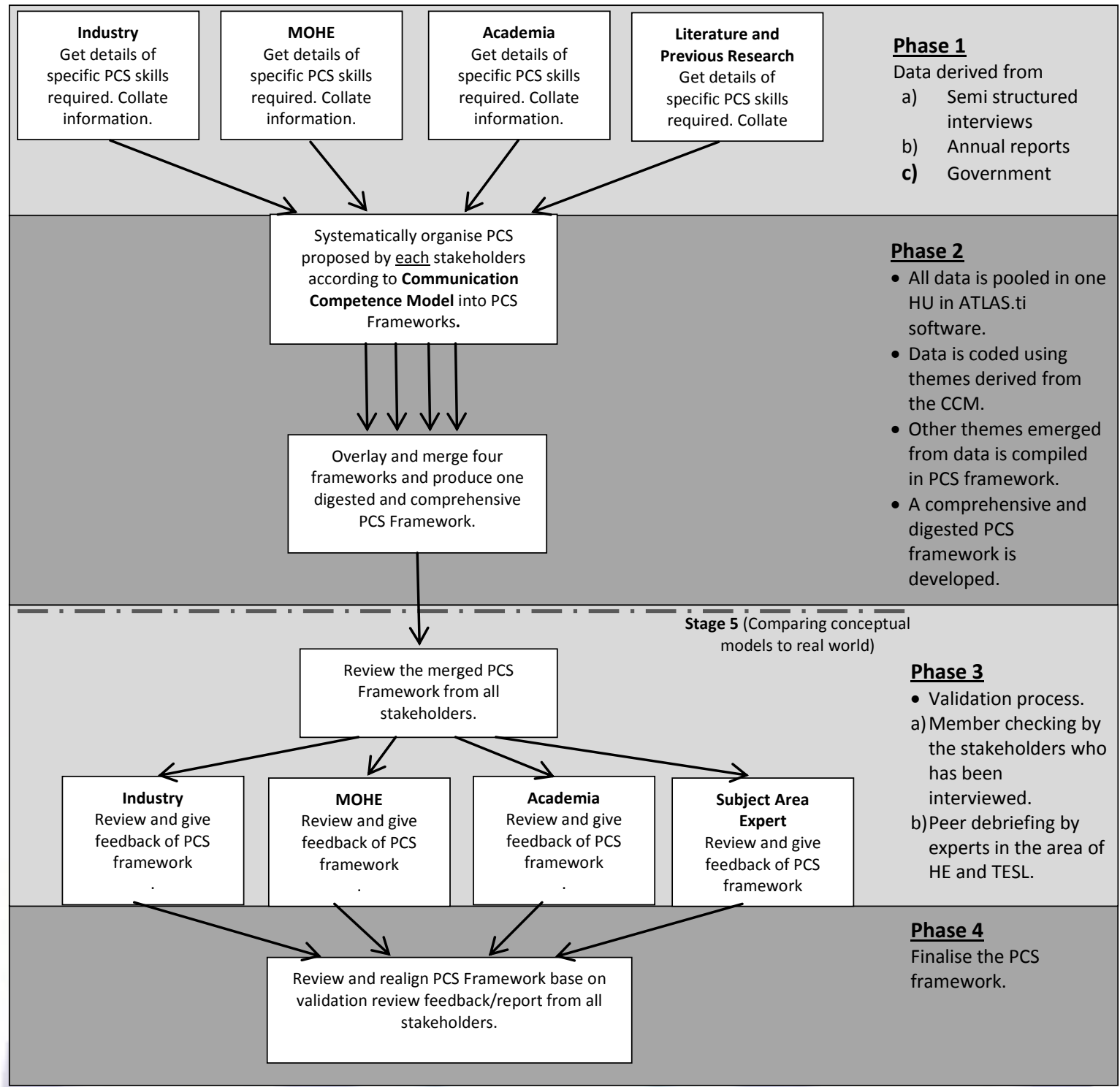

\section{Conclusions and Further Work}

All in all, SSM was conceived as a framework for the inquiry into ill-structured situations. It "...provides a general set of concepts and an intellectual framework for articulating the search for 'images of reality' which are relevant to taking purposeful action within some problem situation" (Ledington and Donaldson, 1997). Checkland's 7 -stage model progresses from finding out about a situation to taking action to improve it. During stages 1 and 2 the problem is still unstructured and expressed by the participants in a rich picture. Stages 3 and 4 involve systems thinking. Root definitions and conceptual models of possibly relevant systems are developed. Stages 5 and 6 are functioned for "find(ing) a version of the real situation and ways to improve it which different people with different worldviews can nonetheless live with" (Checkland and Poulter, 2006, p. 54). There are different ways to achieve this activity, but an approach used heavily is the one used in the present research: formal questionings during interview sessions (Checkland and Poulter, 2006). Finally, the last stage is used for applying the debated and reviewed model in the real world.

This study has demonstrated that SSM can be used as a framework to investigate a problem within the Malaysian educational discipline. The benefits that can be derived from its use are primarily its ability to focus on issues and dwell in depth with the whole system as compared to the quantitative results-driven and analytical quality assurance processes that are traditionally used to assess the effectiveness of a module. Additionally, being a methodology that can deal with complex organisational and hierarchical situations where those involved may lack of a common agreement, SSM offers the best solution by giving the stakeholders involved a proper stage to voice out their opinion. It promotes shared thinking and helps to persuade people to work together and find a common ground. 
Apart from that, the findings can contribute significantly to the knowledge and development of English for Occupational Purposes courses since this study has generated an informed framework for PCS (See Appendix A). Because of this, taught courses that should contain PCS in Malaysia HE institutions like English for Occupational Purposes or English for Workplace would discontinue to take multiple forms. Even though there is much work to be done, this study is the first of its kind in Malaysia and would help in increasing the quality of institutions of higher education in Malaysia.

\section{REFERENCES}

[1] Avenier, M. (2002). Designing a Collective Undertaking and Systemic Modelling : Potentially Fertile Concepts. Res-Systemica, 2, 1-5.

[2] Checkland, P. (2000). Soft Systems Methodology: A Thirty Year Retrospective. Systems Research and Behavioral Science, 17, $11-58$.

[3] Checkland, P., \& Poulter, J. (2010). Systems Approaches to Managing Change: A Practical Guide. (M. Reynolds \& S. Holwell, Eds.) (pp. 191-242). London: Springer London. doi:10.1007/978-1-84882-809-4

[4] Delbridge, R. (2011). An illustrative application of soft systems methodology ( SSM ) in a library and information service context Process and outcome. Library Management, 29(6), 538 - 555. doi:10.1108/01435120810894545

[5] Department of Innovation, Industry, Science, R. and T. E. (2012). Strengthening Foundation Skills in the Workplace An evaluation of the Workplace English Language (p. 84). Canberra.

[6] Gill, S. K. (2005). Language Policy in Malaysia: Reversing Direction. Language Policy, 4(3), 241-260. doi:10.1007/s10993-005-7859-9

[7] Hassan, S. (2012). The Soft Systems Methodology Based Analysis Model in the Development of Selfmanaging Information Systems Sa ' Adah Hassan Department of Information Systems Faculty of Computer Science and Information Technology ,. Journal of Computer Science, 8(3), 366-373.

[8] Hindle, G. a. (2011). Case Article: Teaching Soft Systems Methodology and a Blueprint for a Module. INFORMS Transactions on Education, 12(1), 31-40. doi:10.1287/ited.1110.0068ca

[9] IPPTN, N. H. E. R. I. (2010). UNIVERSITY CURRICULUM AND EMPLOYABILITY NEEDS (p. 8). doi:378.0720595

[10] Koo, Y. L., Pang, V., \& Mansur, F. (2007). Employer Perceptions on Graduate literacies in Higher Education in Relation to the Workplace. ESP World, (18), 1-16. Retrieved from http://www.espworld.info/Articles_20/DOC/Koo_vp_employer_Journal18Oct09.pdf. 2009

[11] Ledington, P. \& J. Donaldson. (1997). Soft OR and management prac- tice: A study of the adoption and use of soft systems methodology. J. Oper. Res. Society 48(3) 229-240.

[12] Lim, H. (2008). Feasibility of Early Identification of Low Employability Graduates in Malaysia, 45(2), 95-112.

[13] Liu, W. B., Meng, W., Mingers, J., Tang, N., \& Wang, W. (2012). Developing a performance management system using soft systems methodology: A Chinese case study. European Journal of Operational Research, 223(2), 529-540. doi:10.1016/j.ejor.2012.06.029

[14] Mohd Radzuan, N. R., \& Kaur, S. (2010). A Survey of Oral Communication Apprehension in English among ESP Learners in an Engineering Courese. English for Specific Purposes, 10(31), 1-14.

[15] Morcos, M., \& Henshaw, M. (2009). A Soft Systems Methodology for Transforming Organisations to ProductService Systems (Application In Defence and Construction Industry ). In 7th Annual Conference on Systems Engineering Research (Vol. 2009).

[16] Noor Azina, I. (2011). GRADUATES ' CHARACTERISTICS AND UNEMPLOYMENT : A STUDY AMONG MALAYSIAN GRADUATES. Internation Journal of Business and Social Science, 2(16), 94-102.

[17] Patel, N. V. (1995). Application of soft systems methodology to the real world process of teaching and learning. International Journal of Educational Management, 9(1), 13-23. doi:10.1108/09513549510075998

[18] Rasul, M. S., Ismail, M. Y., Ismail, N., Rajuddin, M. R., \& Amnah, R. (2009). Importance of Employability Skills as Perceived by Employers of Malaysian Manufacturing Industry. Journal of Applied Sciences Research, 5(12), 2059-2066.

[19] Rose, J. (1997). Soft systems methodology as a social science research tool. Systems Research and Behavioral Science, 14(4), 249-258. doi:10.1002/(SICI)1099-1743(199707/08)14:4<249::AID-SRES119>3.0.CO;2-S

[20] Shafie, L. A., \& Nayan, S. (2010). Employability Awareness among Malaysian Undergraduates. International Journal of Business and Management, 5(8), 119-123.

[21] Tajino, A., \& Smith, C. (2005). Exploratory Practice and Soft Systems Methodology. Language Teaching Research, 9(4), 448-469. doi:10.1191/1362168805Ir178xx 
[22] Venters, W., Cushman, M., \& Cornford, T. (2002). Creating Knowledge for Sustainability : Using SSM for Describing Knowledge Environment and Conceptualising Technological Interventions.

[23] Wong, F. F., \& Ming, T. S. (2010). Developing Academic Competency for Studies in English : The Malaysian ESL Teachers ' Perspective. ESP World, (1), 1-28.

\section{Author' biography with Photo}

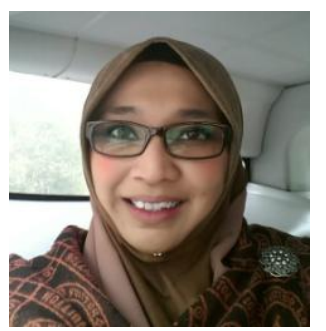

Ahmad-Tajuddin Azza Jauhar is currently attached with Department of Languages and Communication, Center of Fundamental and Liberal Education, Universiti Malaysia Terengganu. Her responsibilities include teaching intercultural communication in the Global Understanding Course, which uses Internet technology to connect UMT students with students from a consortium of international universities. Additionally, she is also teaching English for Occupational Purposes course to third and final year undergraduates. Azza has a doctorate degree in Education from the University of Nottingham and received her Masters of Education (Teaching English as a Second Language) from Universiti Kebangsaan Malaysia. She earned her Bachelor of Education (Teaching English for Speakers of Other Languages) degree at Moray House, University of Edinburgh. Her current spheres of interest in research are teaching English in higher education, English language communication for workplace, program evaluation, employability, intercultural communication, qualitative research, needs analysis as well as using CAQDAS in research, mainly ATLAS.ti. 


\section{APPENDIX A: PROFESSIONAL COMMUNICATION FRAMEWORK IN ENGLISH}

\begin{tabular}{|c|c|c|c|}
\hline $\begin{array}{l}\text { Core Component } \\
\text { (Communicative } \\
\text { Competence Model) }\end{array}$ & $\begin{array}{c}\text { Sub } \\
\text { Component }\end{array}$ & Requirement for workplace & $\begin{array}{c}\text { Examplars: } \\
\text { 'Upon graduation, graduates should be } \\
\text { able to...' }\end{array}$ \\
\hline \multirow[t]{5}{*}{$\begin{array}{l}\text { Cognitive } \\
\text { Knowledge }\end{array}$} & $\begin{array}{l}\text { Content } \\
\text { Knowledge }\end{array}$ & $\begin{array}{l}\text { Contribute to on-going } \\
\text { improvement and expansion of } \\
\text { knowledge in the betterment of } \\
\text { workplace operations. }\end{array}$ & $\begin{array}{l}\text { Build a relevant knowledge base for } \\
\text { workplace. } \\
\text { - Apply their subject content } \\
\text { knowledge at workplace. } \\
\text { - Manage own learning in order to } \\
\text { maintain and renew attributes } \\
\text { throughout working lives. } \\
\text { - Use specific work-related jargon } \\
\text { appropriately in speech and reports. }\end{array}$ \\
\hline & $\begin{array}{l}\text { Cultural } \\
\text { Competence }\end{array}$ & $\begin{array}{l}\text { Contribute to harmonious } \\
\text { relations between superior, } \\
\text { subordinates, colleagues and } \\
\text { clients. }\end{array}$ & $\begin{array}{l}\text { Speak and write using the most } \\
\text { appropriate register. } \\
\text { - Agreeing/Disagreeing with the } \\
\text { superior and subordinate in a } \\
\text { diplomatic manner. } \\
\text { - Adapt with small talks with } \\
\text { colleagues, being aware with context } \\
\text { awareness. }\end{array}$ \\
\hline & $\begin{array}{l}\text { Linguistic } \\
\text { Competence }\end{array}$ & $\begin{array}{l}\text { Contribute to meaningful and } \\
\text { effective conversations using } \\
\text { appropriate workplace discourse. }\end{array}$ & $\begin{array}{l}\text { - Organise spoken and written } \\
\text { language during a variety of } \\
\text { communication tasks at workplace. } \\
\text { - Present their speech and written } \\
\text { work using appropriate vocabulary } \\
\text { and fluency. } \\
\text { - Clearly and accurately articulate } \\
\text { words during workplace activities. }\end{array}$ \\
\hline & $\begin{array}{l}\text { Critical } \\
\text { thinking }\end{array}$ & $\begin{array}{l}\text { Contribute to constructive } \\
\text { criticism while resolving issues at } \\
\text { workplace. }\end{array}$ & $\begin{array}{l}\text { - Critically synthesising their thoughts } \\
\text { in a professional manner to improve } \\
\text { situation. } \\
\text { - Identify, analyse and solve problems } \\
\text { critically and innovatively. } \\
\text { - Give positive feedback and healthy } \\
\text { criticism after analysing issues at } \\
\text { workplace. }\end{array}$ \\
\hline & Tasking skill & $\begin{array}{l}\text { Contribute to productive long- } \\
\text { term and short-term strategic } \\
\text { planning and effective execution } \\
\text { of workplace tasks. }\end{array}$ & $\begin{array}{l}\text { - Organise thoughts and solve } \\
\text { workplace problems and issues. } \\
\text { - } \quad \text { Argue politely in generating solutions } \\
\text { and alternatives in workplace issue. } \\
\text { - } \quad \text { Synthesise issues at work and } \\
\text { evaluate solutions individually. }\end{array}$ \\
\hline
\end{tabular}




\begin{tabular}{|c|c|c|c|}
\hline \multirow[t]{3}{*}{$\begin{array}{l}\text { Communication } \\
\text { Skills }\end{array}$} & $\begin{array}{l}\text { Interpersonal } \\
\text { Communication }\end{array}$ & $\begin{array}{l}\text { Contribute to diplomatic and } \\
\text { matured communication } \\
\text { between superior, subordinates } \\
\text { and clients. }\end{array}$ & 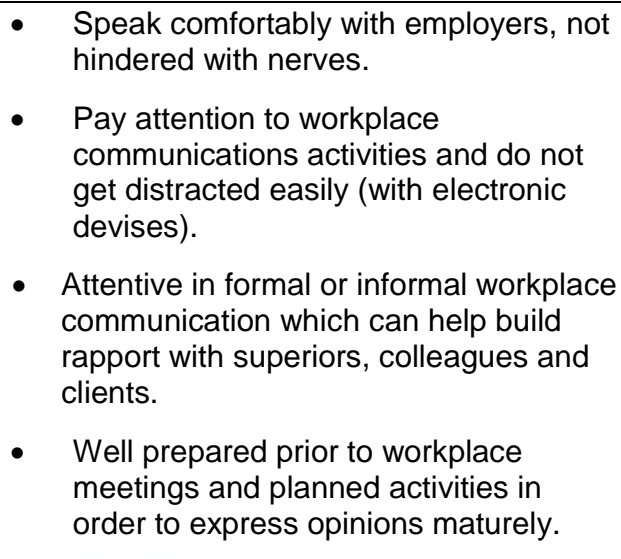 \\
\hline & Presentation Skill & $\begin{array}{l}\text { Contribute to sharing of ideas } \\
\text { and thoughts effectively with } \\
\text { superior, colleagues and } \\
\text { clients. }\end{array}$ & $\begin{array}{l}\text { - } \begin{array}{l}\text { Able to share ideas with colleagues } \\
\text { creatively. }\end{array} \\
\text { Able to persuade clients to accept their } \\
\text { ideas by explaining in a simple yet } \\
\text { interesting manner. } \\
\text { - Inform superiors of new innovative } \\
\text { measures in improving workplace. } \\
\text { Keep spectators' attention using range } \\
\text { of presentation skill, with the help of IT } \\
\text { as a management tool. } \\
\text { Responding to enquiry from the clients. }\end{array}$ \\
\hline & Speaking skill & $\begin{array}{l}\text { Contribute to productive and } \\
\text { appropriate verbal interactions } \\
\text { at workplace. }\end{array}$ & $\begin{array}{l}\text { - } \quad \text { Inform audience (superiors, colleagues } \\
\text { and clients) in an enlightening manner. } \\
\text { - } \quad \text { Contributing ideas and give opinions in } \\
\text { group discussions. } \\
\text { - } \quad \text { Persuade superiors, colleagues and } \\
\text { clients to accept ideas and opinions } \\
\text { using well-defined explanations. } \\
\text { - } \quad \text { Use specialist vocabulary in a correct } \\
\text { manner. } \\
\text { - } \text { Give clear instructions to solve issues } \\
\text { at work. } \\
\text { Initiating contact, requesting } \\
\text { information on the telephone. } \\
\text { - Seeking information from others at } \\
\text { work. } \\
\text { Responding to enquiries/problems } \\
\text { from superior/clients. } \\
\text { - } \text { State reasons for disagreeing without } \\
\text { interrupting the speech of colleagues } \\
\text { or superiors } \\
\text { Discussion work schedules and } \\
\text { procedures. } \\
\text { Engage small talks with superior, } \\
\text { colleagues and clients informally. } \\
\text { answering inquiries, giving instructions. }\end{array}$ \\
\hline
\end{tabular}




\begin{tabular}{|c|c|c|c|}
\hline & $\begin{array}{l}\text { Non-verbal } \\
\text { communication }\end{array}$ & $\begin{array}{l}\text { Contribute to the ease and } \\
\text { comfort during interactions. }\end{array}$ & $\begin{array}{l}\text { - Appropriately dressed according to } \\
\text { workplace occasions. } \\
\text { - Be on time in all workplace functions. } \\
\text { - Control own nerves in meetings with } \\
\text { superior and clients in order to be less } \\
\text { agitated. } \\
\text { - Ensure their body language is not } \\
\text { offensive during conversations with } \\
\text { colleagues, superiors and clients. } \\
\text { - Wear pleasant facial expression. }\end{array}$ \\
\hline \multirow[t]{3}{*}{$\begin{array}{l}\text { Communication } \\
\text { Skills }\end{array}$} & Listening Skill & $\begin{array}{l}\text { Contribute to successful } \\
\text { working relationships and } \\
\text { effective execution of tasks. }\end{array}$ & $\begin{array}{l}\text { - Ask if one does not understand } \\
\text { instruction by superior, colleagues and } \\
\text { clients. } \\
\text { - Disagree politely if better ideas can be } \\
\text { brought up. } \\
\text { - Respond appropriately (speech or non- } \\
\text { verbal communication) after } \\
\text { understanding the instructions, } \\
\text { questions, etc. } \\
\text { - Fully comprehend what is going on } \\
\text { around them at workplace. } \\
\text { - Give feedback when asked by } \\
\text { colleagues, superior and clients after } \\
\text { fully understanding the situation. } \\
\text { - Responds to clients' complaints. }\end{array}$ \\
\hline & ${ }^{*}$ Writing Skill & $\begin{array}{l}\text { Contribute to effective } \\
\text { execution of tasks at work and } \\
\text { making the work flow efficient. }\end{array}$ & $\begin{array}{ll}\text { - } & \text { Filling in forms. } \\
\text { - } & \text { Write memo. } \\
\text { - } & \text { Write formal business letter } \\
\text { - } & \text { Write minutes of meeting } \\
\text { - } & \text { Write for the company's website } \\
\text { - } & \text { Write formal/informal email messages } \\
\text { - } & \text { Write items for newsletter } \\
\text { - } & \text { Write reports using office template. }\end{array}$ \\
\hline & ${ }^{*}$ Reading Skill & $\begin{array}{l}\text { Contribute to proficient job } \\
\text { execution and high quality } \\
\text { results at workplace. }\end{array}$ & 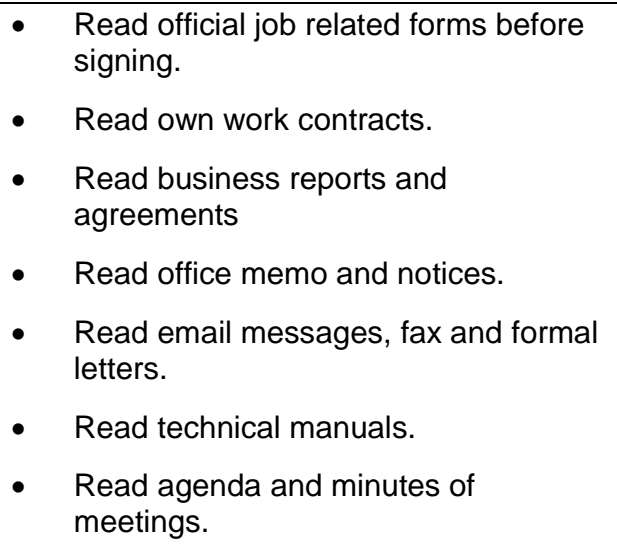 \\
\hline
\end{tabular}




\begin{tabular}{|l|l|l|l|}
\hline & & $\bullet$ & Read work related books and articles. \\
\hline Motivation & $\begin{array}{l}\text { Positive } \\
\text { motivation }\end{array}$ & Contribute to job satisfaction. & $\begin{array}{r}\text { Aware that communicating fluently and } \\
\text { confidently in English language can } \\
\text { help secure a job in public and private } \\
\text { sectors. }\end{array}$ \\
& & $\begin{array}{l}\text { Understand that speaking, listening } \\
\text { and writing in good English will benefit } \\
\text { them in terms of climbing up the } \\
\text { workplace ladder quicker. }\end{array}$ \\
& & $\begin{array}{l}\text { Be confident in speak English publicly } \\
\text { to superiors, colleagues and clients. } \\
\end{array}$ & $\begin{array}{l}\text { Control own anxiety while speaking to } \\
\text { an unknown group of new clients. }\end{array}$ \\
& & \\
& & \\
& & \\
& & \\
& &
\end{tabular}

